\title{
Burmese Women Portrait Under the British Imperialism in Orwell's Burmese Days
}

\author{
Nur Afiah \\ English Language Studies Postgraduate Program, Faculty of Cultural Sciences, Hasanuddin University, Makassar, \\ Indonesia \\ Burhanuddin Arafah \\ English Department, Faculty of Cultural Sciences, Hasanuddin University, Makassar, Indonesia \\ Herawaty Abbas \\ English Department, Faculty of Cultural Sciences, Hasanuddin University, Makassar, Indonesia
}

\begin{abstract}
This study aims to expose the Burmese women portrait under British Imperialism. The writer believes that Burmese Days is created as a response to the social phenomenon that was happening during the process of its creation. This study used a qualitative method using a sociological approach by Laurenson and Swingewood. The data of this study were collected from the description and utterances of the characters and narrator in the novel. The result of this study shows that the women were portrayed as the slave of the English men. The women are not valuable, they merely become entertainment for the English men to entertain them. Even, some of the Europeans have concubines to accompany them in killing their time or killing their boredom. It looks like the women are created for the English men as dolls which can be played as often as they can, and of course, like a doll, they can be thrown easily after the English men being bored. As this research limited to the analysis of women portrait as a concubine for the English men, it is suggested for other researchers to analyze and find the relevant problems that still exist around the society, such as social inequality, resistance, obedience, strategy, gender, racism, corruption and other social aspects in the novel Burmese Days.
\end{abstract}

Index Terms-women portrait, British imperialism, Burmese Days, George Orwell

\section{INTRODUCTION}

Nowadays most people define literature as a written piece of work containing aesthetic merits produced by authors (Arafah, B., Kaharuddin, A., Mulyanto., Arifin, M.B., Rofikah, U., Arafah, A.N.B. 2021). The aesthetic merits which are produced by authors are shown by the quality of the literary work which has been written and can be enjoyed by the readers, the literary works are favorably viewed as reading resources that are used for enjoying the scenes, plots, and characters in the works when spending their leisure time (Sunardi, S., Akil, M., Arafah, B., \& Salija, K. 2018). Besides enjoying it as reading material to fill spare time, literary works are not only a story that describes an imagination without value inside but also is a reflection of real-life which was written by the authors through their experience during certain periods in the past specifically. Value refers to something worth which can be used as an individual's standard of behavior in life and the authors commonly express values and ideas play out in the daily life of the people as they found in novels, poems, or short stories (Arafah, K., Arafah, A.N.B., \& Arafah, B. 2020., Arafah, B., et.al. 2020, Kaharuddin., \& Hasyim, M. 2020). It shows that literary works contain many salutary lessons and strong sources of information on reality regarding people's way of life (Purwaningsih, Y. R., Arafah, B., Abbas, H., \& Arafah, A. N. B. 2020). Arafah, Kaharuddin, Mulyanto, et al (2021) state that literary work is rich in varieties such as novels, short stories, comic books, diaries, letters, folktales, fantasies, mysteries, and so on.

The rapid development of the literary works as a response of the reader is caused by the development of the theory of literature. Furthermore, the advances in information technology in this era have also changed the way people thinking (Arafah \& Hasyim, 2019). It means that the style of literature was influenced by the author's thoughts that changed as time passed following the development of an era. In the $20^{\text {th }}$ century, several multidisciplinary theories of literature have developed rapidly such as sociology of literature, anthropology of literature, and psychology of literature (Kaharuddin \& Latif. 2017., Arafah, B, 2018). In literary works, the authors use language as a medium to communicate and interact among the characters in the story. The use of language in the story is aimed to make the readers are more interested in reading the literary works. The language used in the literature is an utterance that performs an act used by the speaker or character in communicating with other characters ( Arafah \& Kaharuddin, 2019). Through the utterances which are shown in the story, the readers are led to give their opinion for the literary works. These readers will convey different opinions based on what they have in their minds. If a reader thinks about something, then he will give an opinion based on the meaning he understands from the utterances in a literary work (Hasjim, Arafah, et.al, 2020). 
Little (1981) argues that literature is also the chief art of mankind because it can effectively express one's idea to others. Meanwhile, Spector and Kitsuse (1977) state that literature usually reveals situations or problems that occur in social life. The problems are called social problems. It is an unusual condition or a form of behavior, which is considered to have deviated from the social norms. Further, Then, Althusser (1971) states in an essay entitled A Letter on Art: in Reply to Andre Daspre that I believe that the college of art is 'make us see', 'make us perceive', 'make us feel' something which alludes to reality. The very complex reality of life that is well connected with fellow citizens can be seen in the storyline in literature. Not just looking at it, but literature is also able to make its readers pay attention to a period when the literary work was created. Through these three processes, there is an implication that the author wants to convey through the literary work presented and the reader will respond to the reality presented by the author in literary works. In the end, the conclusion of these arguments can be argued that literature is a product of art in society. It can be stated that literature is the social product that is equivalent to cultural, political, and social studies issues (Irmawati., Arafah, B., Abbas, Herawaty., 2020).

Literature provides useful information on the most appropriate types of literature such as short stories, poems, novels, plays, as well as songs (Arafah, 2018). From these types of literature, some people are more interested in reading a novel. Laar and Schoonderwoerd (1963) define a novel as work as far as introducing us to a living world; in some ways resembles the world in which we live, but with its individualist. By reading this, the writer views that literature is an author's expression during its period. By their imagination and social fact which was happening around them in a certain period, they write various stories and that story nowadays can be a satire for a certain people. It looks like that the literary works can be an alarm for people.

The study aims to describe women's portraits in the past. The term which talks about women is called feminism. Brunell \& Burkett (2019) \& Beasley (1999) argue that feminism is a range of social movements, political movements, and ideologies that aim to define and establish the political, economic, personal, and social equality of the sexes. Women are one of the most interesting issues to be discussed. They have not been deeply discussed until now. Many things which are related with the women, such as discrimination, gender, freedom, inequality, independence, slavery, women's right and women's desire. One of the most common cases involving women is discrimination and slavery.

In the past, women's condition was described as weak so the women always got discrimination against the men. Through discrimination, the women were presented as inferior. In addition, Orwell's Burmese Days presented the slavery of women. Women's slavery is the worst side of British Imperialism which should be accepted by the Burmese. They do not have any power to fight them up. They just follow the British order, they know that their town was really poor, outdated, before the British come to colonize them and build them a civilization towards progress. The British emphasize that the Burmese people are uncivilized and uneducated citizens. Most women become concubines for every white man or woman in slavery, and the cost for every woman is cheap enough. "The woman was Ma Hla May, Flory's mistress... He was a woman of twenty-two or-three, and perhaps five feet tall... Flory had bought her from her parents two years ago, for three hundred rupees" (Orwell, 1962, p. 51-53). In contrast in this era, this world is surrounded by a cacophony of news that women are willing to sell themselves for men to gain money and making it their job (Purwaningsih, Arafah, \& Abbas, 2020).

By reading this, the writer argues that women's slavery will exist as long as the women are not respected at all. Through this story, Burmese days novel, shows vividly that at that period in Burma, women-only is concubines or mistresses for the Europeans. In addition, the researcher believes that Orwell's work, Burmese Days is a mirror of the age of society in that period, for women specifically. Burmese women are treated worst by British men. They deserve to be treated whatever they want because they have bought it or paid for it every time they make love. Buddhist is the largest religion for the Burmese people in Myanmar. For them, whose religion is Buddhist, they believe that the one who has done an evil along with their lives, they will spend their life in the incarnation whose shape is similar with a rat, a frog, and other low animals. In addition, they also believe as the Buddhists that the women's position is the same as a rat or a frog.

The writer assumes that the British treat the Burmese women like an animal because of the Buddhist belief toward the women at that period. Coming from all these facts that happened in Burma, Orwell utilizes the history and cultural heritage owned by every country or region to produces a literary work (Hayim, Arafah, \& Kuswarirni, 2020). It also makes Orwell write this novel because behind this writing many events happening at the time, and by writing this, he shows his concern toward the Burmese people under the British Imperialism. Myint-U (2001) defines a lot about Burma before being colonized by the British. He describes that Britain had colonized India and then the conflict between Burma and Britain occurred because the Konbaung dynasty decided to expand to Arakan in the state of Assam, near British-controlled Chittagong in India. This led to the First Anglo-Burmese War (1824-26). The British sent a large expedition at sea that took Rangoon without a fight in 1824. At Danuphyu, in the Ayeyarwady Delta, General Maha Bandula of Burma was killed and his army was defeated. Burma was forced to give up Assam and other northern provinces. Further, Anthony (1998) adds that the Yandabo Treaty of 1826 officially ended the First Anglo-Burmese War, the longest and most expensive war in British Indian history. Fifteen thousand European and Indian soldiers died, along with an unknown number of Burmese soldiers and civilian casualties. The campaign cost Britain between 5 and 13 million pounds sterling which led to the economic crisis in British India in 1833. 
George Orwell is one of the leading novelists of the modern age. Orwell's Burmese Days is a literary work that has become a part of the mythology of imperial experience not only for Burma but for the British Empire as a whole. Stephen (2005) states that Burmese Days are often assigned to complement general service courses in world history, literature, and political science. The political and social hypocrisies are powerful satire in his novels. Burmese Days was his first novel published in 1934, written when he worked in the Indian Imperial Police in Birma, now is Myanmar, from 1922 until 1907. During the involvement in the police, he did a lot of torture on the prisoners, the peasants, and an old advance, and the servants and laborers whom he had beaten with his stick. His great quality of writing delivers him to achieve international fame and recognition. Orwell emphasizes the relationship between literature and politics and economic issues in most of his works. Through his fiction writings, Burmese Days, Animal Farm, Nineteen Eighty-Four, declare him as a political thinker and it is undoubtedly.

Orwell concerns also toward the problems faced by the Burmese. No wonder, there are many differences among them. The color of the skin, body posture, intelligence, gender, racism, corruption, women's slavery make the British proud and be the superiority and the Burmese are always be the inferiority. By seeing all the complex problems faced by the Burmese under the British Imperialism, it makes Orwell pouring his experiences during staying in Burma and joining Imperial Police for five years became a story which is written in the novel and performed by some characters, the Europeans and the Burmese specifically.

Burmese Days novel is set in Burma, Myanmar, and Kyauktada is the fictional district in the story. It is a town where Orwell served for five years in the 1920s during Imperial Burma. OED In Loomba (2000) defines "imperial" as simply something that "refers to kingship", and "imperialism" as the rule of an emperor, especially despotic and arbitrary ones; the principle or spirit of kingship; the act of advancing the interests of the empire. Further, William (1976) states that imperialism is supreme or superior power. It can be assumed that imperialism is a practice of some countries which targets territorial expansion and control of markets, including the deprivation of material resources and interference in a political and cultural system against the territory it occupies. Right under British Imperialism, there some impacts were given to the Burmese people. As the colonizer and the white skin men who have power in Burma, they build some buildings. At the time, Burma was portrayed as the slum town under the British Imperialism which is Kyauktada as the government center, "Kyauktada was a fairly typical Upper Burma town... in 1910 the Government made it the headquarters of a district and a seat of Progress-interpretable as a block of law courts... durable jails which the English have built everywhere" (Orwell, 1962, p. 18).

Many researchers have been analyzed the same topic, Orwell's Burmese Days such as Perdana and Wardhani which analyzed crisis of identity and mimicry (2017), then Dewi, Priyatna, Aksa analyzed the masculinity of the white men (2013), and Anjasari analyzed anti-racism in Orwell's travel writing (2015). The differences between this study and these previous researches lie on the main object, this study focuses on the Burmese women portrait under the British Imperialism.

\section{LITERATURE REVIEW}

Durkheim (1958) argues that sociology can be understood as the discipline that aims to study human behavior, the formation of a social structure, and a joint agreement in the economy, politics, culture, and others. In addition, Uer (2013) describes three realities in literature and sociology. Firstly, the reality in sociology is factual which is the social fact of human life, while the reality in literary works is a fictional fact, author's imagination by using language metamorphosis which touching the reader. Secondly, sociology describes the social phenomena by using denotative meaning and it is easy to analyze without causing any other interpretations, whereas in literary works the social phenomena are described by using connotative meaning which rising some interpretations and touching the reader's feelings. Thirdly, the sociologist processes their thoughts and feelings more rationally so that they are easily understood by the readers, while the literary author processes their thoughts and feelings emotionally. From the two explanations above, the writer concludes that sociology describes reality and social fact by using straightforward language as a medium to deliver to the society, whereas literature describes a fictional through the authors' imagination which using connotative language and as a result from some readers, they have some interpretations about that. Nevertheless, the existence of literature cannot be separated from the social reality which occurs in society. The source of this research is a novel from Orwell, Burmese days, while the data are the result of analyzing the women portrait under the British Imperialism in Burmese Day's novel written by Orwell.

In this study, the writer uses the theory by Laurenson and Swingewood, sociology of literature. Laurenson and Swingewood (1972) introduce three perspectives in their theory, as follows: first is the research which considering the literary work as a mirror of age. The second is the research that considering the literary works as the sociology of the authors, and the third is the research that considering the literary work as a manifestation of historical events and the social culture condition.

Laurenson and Swingewood (1972) argue that literature as a mirror of age deals with the time when literary works are created and set. It indicates that the readers can discuss the social phenomenon which happens to the society in a certain period and certain place through the literary work. In addition, literary work deals with the social situation of the author, it looks like the author is influenced by the situation and condition where the literature is written because the author is a member of the society. Further, literary work is as the specific historical moment, it shows the condition of 
society in certain times in accepting and understanding a literary work, the work has special issues in the history which make it become an interesting work.

Those explanations above can be viewed that literary works are created through the phenomena which occur in the society in a certain period and certain place and also the author is always inspired by the happening in his society. In this case, the authors have to be more sensitive toward the social phenomena surrounding them. In addition, literary works reflect the essence, abridgment, and summary of all history. Furthermore, it cannot be separated by the author's manners and attitudes because those things reflect automatically through his works, and by knowing that, the readers understand fully the style of his works.

\section{METHOD}

Leedy \& Ormrod (2001) state that research is the process of collecting, analyzing, and interpreting data to understand a phenomenon. This research is a qualitative descriptive method using the sociology of literature approach by Laurenson and Swingewood. This method is used by collecting the whole data then explained in detail, and words, descriptions, and dialogues were the data. Library research was the first step for collecting the data. The writer reads the main source of this study, Orwell's novel Burmese Days, published in 1962 by Harcourt, New York. Besides reading the novel, the writer also read some journals, articles, some thesis, and books related to this study to add some sources. Then, the writer marked the descriptions to collect the data related to the women's portrait in the novel.

\section{RESUlt AND DisCUSSION}

In Burmese Days, Orwell describes his concern toward the Burmese who faced many problems under British Imperialism. Many aspects that Orwell concerns about at the time, he realized that racism, gender, corruption, women slavery, lying, cheating, are the complex problems faced by the Burmese. Orwell served with the Imperial Police in Burma for five years, he saw what the British did toward the Burmese. Through his writing, he blew up his anger toward the British and covered it with a fictional story. Surely, he wrote this story based on his experience during staying in Burma. Here, the writer only focuses on women slavery portrays in Burmese Days as the character performs under British Imperialism. At the time, the women are easy to own by buying and selling at the lowest price. So that, most of the British have some concubines or mistress. Then, being bored of the mistress, they are easy to buy another mistress. "There is also a young village girl with a baby. She says that the baby is yours, the holiest one... It did not take him long to deal with the other visitors and to send the village girl away unrewarded, having examined her face and said that he did not recognize her" (Orwell, 1962, p. 8-13). This passage vividly shows that the woman's position merely lies on concubine or mistress for some of the men. This passage illustrates that asking the responsibility to the man, the man easily does not admit then expels the woman without getting anything, even money for the baby.

Another evidence of the women in that period can be seen by the English men illustration which is illustrated by the narrator. "Mr. Macgregor is of the type of the Fine Old English Gentleman, such as, in these happy days, we have so many examples before our eyes. He is "a family man" as our dear English cousins say. Very much a family man is Mr. Macgregor. So much so that he has already three children in the district of Kyauktada, where he has been a year, and in his last district of Shwemyo he left six young progenies behind him. Perhaps it is an oversight on Mr. Macgregor's part that he has left these young infants quite unprovided for, and that some of their mothers are in danger of starvation, etc., etc., etc" (Orwell, 1962, p. 9-10). In addition, to show clearly about the English men, the narrator adds a sentence to support the situation in that time. "Mr. Lackersteen, drunk, supported on either side by a naked Burmese girl, while a third up-ended a whisky bottle into his mouth" (Orwell, 1962, p. 21). Besides Mr. Macgregor and Mr. Lackersteen, there is also Flory who has a concubine also. "The woman was Ma Hla May, Flory's mistress" (Orwell, 1962, p. 51). These quotations state that the English men, wherever they are, it is sure that they have some concubines, two of them are Mr. Macgregor and Mr. Lackersteen. Both of them invite some concubines or mistresses to accompany them in their leisure time or to kill their boredom time. The English men do not want to marry the Burmese woman because of the different colors they have.

In supporting the Burmese women's portrait right under British Imperialism, the author describes the English men's treatment toward the women. The English men portray as rude, never respect the women, even though toward the Burmese women. They do not even consider them. For the English men, the Burmese women are the entertainment only to kill their time. "The girls he has ruined, raping them before the very eyes of their mothers!" (Orwell, 1962, p. 45). This sentence shows that how to disgust his action toward the girl is. Even, he never considers that his acts can hurt the girl and her mother herself. It shows also that it is totally clear that the girl or woman has never had dignity in front of the man.

The writer has written that almost the English men have concubines, but the author vividly emphasizes the one who has a concubine who stays more than 2 years. It is Flory whose concubine's name is Ma Hla May. "So you would rather sleep alone than with Ma Hla May? How ugly you must think me, then! Am I ugly, master?... "Go away," he said, pushing her back. "I don't want you at this time of day" (Orwell, 1962, p. 52). This illustration exposes that Flory treats Ma Hla May rudely. In addition, Flory's description of his concubine shows that he does not need her anymore. "Two years ago you would have redeemed them for me. Ah, you do not love Ma Hla May any longer!” (Orwell, 1962, p. 52). 
Completely, Ma Hla May remembers that two years ago she was Flory's wife who was bought from her mother with the lowest price. Ma Hla May does not want to leave Flory because of money. He gets a lot of money after making love or accompanying Flory for sleeping. "Go away, go away!" he said angrily. "Look in the pocket of my shorts. There is money there. Take five rupees and go"... "Get out of this room! I told you to go. I don't want you in here after I've done with you"... "That is a nice way to speak to me! You treat me as though I were a prostitute"... "So you are. Out you go," he said, pushing her out of the room by her shoulders. He kicked her sandals after her. Their encounters often ended in this way. (Orwell, 1962, p. 55). No wonder, Flory's attitude toward Ma Hla May is impolite. Flory thinks that his concubine or mistress will obey him because he gives her a lot of money after making love. So he never thinks about his concubine's feelings.

Another reason why Flory treats badly Ma Hla May is that Flory has fallen in love with the English woman. Ma Hla May knows that and she wants to keep Flory to stay by her side. "Ma Hla May knew, and all the servants knew, that he was getting rid of her because of Elizabeth. Because of "the Ingaleikma with dyed hair", as Ma Hla May called her"..." Ma Hla May was clinging to the gatepost and Ko S'la was trying to bundle her out" (Orwell, 1962, p. 113-145). In addition, Ma Hla May's anger has been expressed in front of Flory. "Ah, what shame, what shame! Two years I was your wife, you loved me and cared for me, and then without warning, without reason, you drove me from your door like a dog. And I must go back to my village, with no money, with all my jewels and silk longyis gone". These passages show that when Ma Hla May knows that Flory will leave her because of another English girl, she gets angry, she could not accept it because she feels that she deserves to have Flory as her master. She thinks that for more than two years, her life only treats Flory well and she will never want to be left by Flory. For her, Flory is her money resource, so that she will not let Flory leave her easily. She will do anything to keep Flory by her side even if Flory treats her worse than two years ago.

\section{CONCLUSION}

In line with the idea of Laurenson and Swingewood (1972) states that literary work is socio-culture records that can be used to see the phenomenon in society during this period, it is significant to restate that these are called literary records which refer to the mirror of age. Orwell's Burmese Days is one of the historical records by the author when he became police in Indian Imperial Police in Birma, now is Myanmar, from 1922 until 1907. Being police, he expresses his anger toward the British who colonized the Burmese in the past, and Burmese Days novel is his masterpiece work to express and illustrate the complicated situation in Burma under British Imperialism.

The English men come to colonize them under British Imperialism. Besides colonizing their country, robbing their natural resources, and ruling them through their law, the English men also colonize the women. No freedom for the Burmese women. The English men consider that the country is poor enough, has no abundance of food, many criminals happen every day. So, most of the women are never worried about being bought by the English men.

In Burmese Days, Orwell illustrates many problems in the past among the English men and the Burmese people. As the result of the Burmese women portrait performed in the story, the writer concludes that the author through its fictional story concerns with the situation which was faced by the Burmese people, particularly the women. No wonder, Burmese women are treated worst like an animal. No price for them unless the lowest price, no respect for them, the English men show no politeness toward them.

\section{REFERENCES}

[1] Althusser, Louis. (1968). Philosophy as a Revolutionary Weapon. Translated by Benjamin Brewster. (1971). Lenin and Philosophy and other Essays. London: Monthly Review Press.

[2] Anjasari, Fitrilya. (2015). Anti-Rasisme Dalam Novel Perjalanan Burmese Days Karya George Orwell. Jurnal Poetika, 3 (1), 67-74.

[3] Arafah, B. (2018). Incorporating the Use of Literature as an Innovate Technique for Teaching English. KnE Social Sciences, 2018, 24-36.

[4] Arafah, B. \& Kaharuddin. (2019). The Representation of Complaints in English and Indonesian Discourse, Opción, 35 (24), 501-517.

[5] Arafah, K., Arafah, A.N.B., \& Arafah, B. (2020). Self-Concept and Self-Efficacy's Role in Achievement Motivation and Physics Learning Outcomes. Opción, 36 (27), 1607-1623.

[6] Arafah, B. \& Hasyim, M. (2019). Linguistic Functions of Emoji in Social Media Communication. Opción, 35 (24), $558-574$.

[7] Arafah, B., Kaharuddin, A., Mulyanto., Arifin, M.B., Rofikah, U., Arafah, A.N.B. (2021). The Idol: An Innovative Model for Designing Literature-Based Elt Materials.Linguistica Antverpiensa, Issue 1, 2075-2090.

[8] Arafah, B., Thayyib, M., Kaharuddin, \& Sahib, H. (2020). An Anthropological Linguistic Study on Maccera' Bulung Ritual, Opción, 36 (27), 1592-1606.

[9] Beasley, Chris. (1999). What is Feminism? New York: Sage.

[10] Brunell, Laura; Burkett, Elinor. "Feminism". Encyclopedia Britannica. Retrieved 21 May 2019.

[11] Dewi, N. R., Priyatna, A., Aksa, Y. (2013). The Masculinity of White Men in George Orwell's Burmese Days and Shooting an Elephant. METASASTRA, 6 (2), 103-114.

[12] Durkheim, Emile. (1958). The Rules of Sociological Method. Glencoe: Fress Press. 
[13] Hasanah, Uswatun., Arafah, B., Abbas, Herawaty. (2021). The Values of Character Education in Pullman's The Golden Compass. Multicultural Education, 7 (1), 142-148.

[14] Hasjim, M., Arafah, B., Kaharuddin, Verlin, S., Genis, R.A.A. (2020). Principles behind Semantic Relation between Common Abbreviations and their Expansions on Instagram. International Journal of Criminology and Sociology, 9, 2270-2276.

[15] Hasyim, M., Arafah, B., \& Kuswarini, P. (2020). The New Toraja Destination: Adding Value 'Toraja Coffee' of the Sustainable Tourism Development. IOP Conference Series: Earth and Environmental Science, 575 (1), 1-10.

[16] Irmawati, Arafah, B., Abbas, Herawaty. (2020). The Lesson Life of Santiago as Main Character on Coelho's The Alchemist. Jurnal Ilmu Budaya, 8 (1), 32-36.

[17] Kaharuddin, A., Latif, I. (2017). The Essential of Discourse Analysis for Teaching English as a Foreign Language. Yogyakarta, Trust Media Publishing.

[18] Kaharuddin, A., \& Hasyim, M. (2020). The Speech Act of Complaint: Socio-Cultural Competence Used by Native Speakers of English and Indonesian. International Journal of Psychosocial Rehabilitation, 24 (6), 14016-14028.

[19] Keck, Stephen. (2005). Text and Context: Another Look at Burmese Days. SOAS Bulletin of Burma Research, 3 (1), $27-40$.

[20] Laurenson, Diana \& Swingewood, Alan. (1972). The Sociology of Literature. U.S.A: Schocken Books Inc.

[21] Leedy, P. D. \& Ormrod, J. E. (2001). Practical Research Planning and Design. (7th Ed.). Upper Saddle River, N. J: PrenticeHall.

[22] Little, Graham. (1981). Approach to Literature: An Introduction to Critical Study of Content and Method of Writing. Marricaville: Science Press.

[23] Loomba, Ania. (2000). Colonialism/Postcolonialism. London and New York: Routledge.

[24] Orwell, George. (1962). Burmese Days. New York. Harcourt.

[25] Perdana, B.E.G., \& Wardhani, E.D. (2017). Crisis of Identity and Mimicry in Orwell's Burmese Days Seen through a Local Native Character U PoKyin: A Postcolonial Reading. Journal of Language and Literature. 17 (1), 82-96.

[26] Purwaningsih, Y.R., Arafah, B., \& Abbas, H. (2020). An Ambition of Infidelity "Emma Bovary" as Wife: Sexuality Problems. Medica Clinica Practica, 3 (S1):100108, 1-3.

[27] Purwaningsih, Y. R., Arafah, B., Abbas, H., \& Arafah, A. N. B. (2020). Psychological Disorder of Emma Bovary as a Wife toward Sexuality Dissatisfaction in Gustave Flaubert Madame Bovary. Journal of Talent Development and Excellence, 12 (3s), $1382-1389$.

[28] Spector, Malcoom, and John I Kitsuse. (1977). Constructing Social Problem. Menlo Park, Calif: Cummings Publication.

[29] Sunardi, S., Akil, M., Arafah, B., \& Salija, K. (2018). Looking at the Shared Conception of Teaching Literature in an Indonesian ELT Setting. Journal of Language Teaching and Research, 9 (2), 316-327.

[30] Thant, Myint-U. (2001). The Making of Modern Burma. New York: Cambridge University Press.

[31] Uer, Theodorus Uheng Koban. (2013). Sosiologi Sastra. Ende, Flores: Nusa Indah.

[32] Van de Laar, E. \& Schoonderwoerd, N. (1963). An Approach to English Literature. S.Hertogenbosch: L. C. G. Malmberg.

[33] Webster, Anthony. (1998). Gentlemen Capitalist: British Imperialism in South East Asia, 1770-1890. London: Tauris Academic Studies.

[34] Williams, R. (1976). Keywords, A Vocabulary of Culture and Society. New York: Oxford University Press.

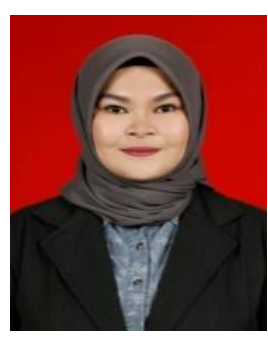

Nur Afiah obtained her Bachelor's degree from Muslim University of Indonesia (UMI) and her Master's degree from Hasanuddin University (UNHAS). She completed her bachelor's degree in English Literature at the Faculty of letters, UMI in 2018. She earned her master's degree in English Language Studies Program, English Language Studies, majoring in English Literature at the Postgraduate Program of the Faculty of Cultural Sciences, UNHAS in 2021.

Her scholarly interests are sociology and literature, sociology of literature, genetic structuralism, and postcolonial. The focus of her master's research is a social value under the British Imperialism in Burma. Her first publication was entitled Burmese Women Portrait under the British Imperialism in Orwell's Burmese Days.

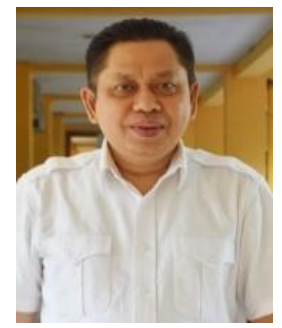

Burhanuddin Arafah obtained his Ph.D. degree in English (Australian) literature at the University of Newcastle Australia in 2003. He earned his Master's degree in American literature at Gadjah Mada University (UGM) Yogyakarta of Indonesia in 1995, and his Bachelor's degree in English literature at Hasanuddin University (UNHAS) in 1988.

$\mathrm{He}$ is currently a full Professor in English literature at the English Literature Study Program, Faculty of Cultural Sciences of Hasanuddin University (UNHAS) Indonesia. He has published 4 books in English language and literature and more than 50 research articles ranked international journals published in the English language. He also has received 24 Intellectual Property Right Certificates from the Indonesian government. His areas of interest are English literature, language education, and cultural studies, He was the Dean of the Faculty of Cultural Sciences of Hasanuddin University in 2009-2017, and currently, he is actively involved at the National Accreditation Board-Higher Education, Ministry of Education and Culture of the Republic of Indonesia for his position as Assessor.

Professor Arafah is currently a member of the Indonesian Literature Scholar Association, and Linguistics and Literature Association of Indonesia, as well as actively involved in the Indonesian Linguistics Society Association. 


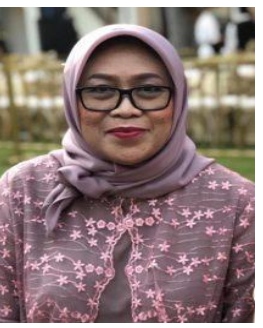

Herawaty Abbas got her Ph.D. at the University of Newcastle Australia in 2013, and her Master's degrees in Gadjah Mada University (UGM) Yogyakarta of Indonesia in 1997 and Saint Mary's University Canada in 2001.

She is currently an Associate Professor at the English Literature Study Program, Faculty of Cultural Sciences of Hasanuddin University Indonesia. Her doctorate thesis examines the potential dialogue between Australian and Buginese culture in terms of feminism. Her research interests are in feminist literature, children's literature, and Indigenous literature. She has published some articles in reputable international journals, such as Women Discrimination in Malaysia: Examining 'The Gender Agenda' from the Viewpoint of Lenore Manderson's Women, Politics, and Change, published in Linguistica Antverpiensia, 2021 (1), 2204 2222; and The Values of Character Education in Pullman's The Golden Compass, published in Multicultural Education, Volume 7 , Issue $1,2021$.

Dr. Abbas is currently a member of the Indonesian Literature Scholar Association, and the Indonesian Linguistics Society Association. 